\title{
RESUMO DE TESE
}

\section{STRONGYLOIDES STERCORALIS: FREQÜÊNCIA EM EXAMES PARASITOLÓGICOS DO HOSPITAL DE CLÍNICAS DA UNICAMP E ANÁLISE MORFOMÉTRICA DAS LARVAS}

\begin{abstract}
Este trabalho foi baseado em dados parasitológicos obtidos de pacientes de ambulatórios e enfermarias do Hospital de Clínicas da UNICAMP durante o período de março de 1993 a fevereiro de 1994. Foi realizado levantamento da ocorrência da infecção por Strongyloides stercoralis entre os pacientes do Hospital. Foi realizada a análise morfométrica das larvas rabditóides e filarióides de $S$. stercoralis provenientes de infecções naturais humanas, com a finalidade de detectar diferentes grupos ou populações de Strongyloides. Foram analisadas 16.940 amostras de fezes no Laboratório de Patologia Clínica do Hospital de Clínicas da UNICAMP. As amostras foram submetidas aos testes parasitológicos de rotina, como: Hoffman, Rugai, Willis e esfregaços diretos. As amostras positivas (20,5\%) foram agrupadas de acordo com sexo, idade, e infecções parasitárias em três grupos: helmintos, protozoários e mistas (helmintos e protozoários). Das amostras analisadas, 11,5\% corresponderam à infecções por protozoários, $7,4 \%$ por helmintos, e 1,6\% por protozoários e helmintos concomitantemente. A freqüência de $S$. stercoralis foi de $4,9 \%$ com predomínio na faixa etária correspondente a 31-60 anos do sexo masculino. Das amostras positivas para $S$. stercoralis, $79,2 \%$ corresponderam a infecções isoladas, 4,7\% associadas a ancilostomatídeos, 8,3\% associadas a protozoários, 5,2\% a outros helmintos, e 2,6\% estavam associadas a outros helmintos e protozoários. Entre os pacientes que apresentaram a infecção, 90 foram escolhidos para base do estudo morfométrico. Os dados foram obtidos através de consulta aos prontuários do Hospital e relataram sintomatologia em $78,9 \%$ desses pacientes. Entre os pacientes sintomáticos, as queixas foram variadas, mas predominaram as relacionadas com o trato gastro-intestinal. A maioria dos pacientes selecionados apresentou
\end{abstract}

Recebido para publicação em 19/07/96.

\section{STRONGYLOIDES STERCORALIS: FREQUENCY OF DETECTION IN PARASITOLOGICAL EXAMINATIONS PERFORMED ATTHE UNIVERSITY HOSPITAL OF UNICAMP AND MORPHOMETRICAL ANALYSES OF LARVAE}

This work was based on parasitological data obtained from in and outpatients attended at the University Hospital of the State University of Campinas (UNICAMP, SP), Brazil from March 1993 to February 1994. A survey of Strongyloides stercoralis infection frequency was made among the hospital patients. The morphometric analysis of rhabditiform and filariform Strongyloides stercoralis larvae was carried out with the finality to detect different groups or species of Strongyloides in natural human infections. At the Clinical Pathology Laboratory, UNICAMP, were analysed 16.940 stool specimens which were submitted on routine parasitological methods, like: Hoffman, Rugai, Willis, and direct faecal smear. The positive sample were grouped according sex, age, and parasitological infections in three groups: helminth, protozoa and mixed (helminth \& protozoa). From positive sample, $11,5 \%$ corresponded to protozoa infection, $7,4 \%$ to helminthic infection and 1,6\% to protozoa and helminthic simultaneous infection. The frequency of S. stercoralis was $4.9 \%$ and predominated in the age-group from 31 to 60 years old of male sex. From the positive $S$. stercoralis sample, $79.2 \%$ corresponded to isolated infection; $4.7 \%$ associated with hookworm; $8.3 \%$ associated to protozoa; $5.2 \%$ with other helminths and 2.6\% were associated to protozoa and other helminths. Among the patients who presented the infection, 90 were selected for the morphometric study. The data were obtained by research of the Hospital records that showed sintomatology in $78.9 \%$ of these patients. Among the symptomatic patients, the related clinical symptoms were variable, but prevailed the gastrointestinal tract complaints. The majority of patients presented until 50 larvae/g faeces.

For morphometric larvae analysis, $1 \mathrm{~g}$ of human faeces were separeted for the quantitative examination. S. stercoralis filariform larvae were obtained from charcoal faecal cultures. Such the rhabditiform larvae obtained from human faeces, 
Resumo de Tese. Teixeira ATLS. Strongyloides stercoralis: freqüência em exames parasitológicos do Hospital de Clínicas da UNICAMP e análise morfométrica das larvas. Revista da Sociedade Brasileira de Medicina Tropical 30:75-76, jan-fev, 1997.

até 50 larvas/g de fezes. Para a análise morfométrica das larvas dos 90 pacientes selecionados, $1 \mathrm{~g}$ de fezes foi separado para exame quantitativo e o restante do material foi utilizado para a cultura em carvão animal granulado para obtenção de larvas filarióides. Tanto as larvas rabditóides obtidas das fezes quanto as provenientes de cultura, foram concentradas pelo método de Rugai, mortas pelo calor, fixadas em TAF. Posteriormente, foram desenhadas em câmara clara e medidas com curvímetro, seguindo critérios morfométricos padronizados. Foram medidas 397 larvas rabditóides e 457 filarióides. As médias das medidas (em $\mu \mathrm{m})$ das larvas rabditóides foram de $385,01 \pm 50,32$ para comprimento total; $97,73 \pm 13,36$ para comprimento do esôfago; $57,76 \pm 8,43$ para comprimento da cauda; 21,12 \pm 4,31 para largura; $194,36 \pm 27,40$ para distância do primórdio à cauda e $27,12 \pm 4,87$ para o comprimento do primórdio genital. As médias das medidas $(\mathrm{em} \mu \mathrm{m})$ das larvas filarióides foram de 505,53 \pm 35,82 para comprimento total; $218,17 \pm 7,86$ para comprimento do esôfago; $58,36 \pm 7,89$ para comprimento da cauda e 15,52 $\pm 2,78$ para largura. A análise estatística das medidas através da técnica de Componentes Principais, não foi capaz de detectar populações ou espécies diferentes de larvas de S. stercoralis nas infecções humanas. as the filariform larvae, were concentrated by Rugai method, died by heat and fixated in TAF. Subsequently, were drawn in camara lucida and measured with curvimeter, by morphometric padronizated parameters. 397 rhabditiform larvae and 457 filariform larvae were measured. The measures (in $\mu \mathrm{m}$ ) obtained for the rhabditiform larvae were $385.01 \pm 50.32$ for total lenght; 97.73 \pm 13.36 for esophagus lenght; $57.76 \pm 8.43$ for tail lenght; $21.12 \pm 31$ for width; $194.36 \pm 27.40$ for the distance between the genital primordium and tip of tail and $27.12 \pm 4.87$ for the genital primordium lenght. The measures (in $\mathrm{m}$ ) obtained for the filariform larvae were: $505.53 \pm 35.82$ for total lenght; $218.17 \pm 7.86$ for esophagus lenght; $58.36 \pm 7.89$ for tail lenght and $15.52 \pm 2.78$ for width. Using the statistical method by Principal Component Analysis (PCA), the measures were not able to detect different species or populations of Strongyloides larvae in human infections.

\section{Angela Terezinha Lauand Sampaio Teixeira}

Tese apresentada à Universidade Estadual de Campinas para obtenção do Título de Mestre.

Campinas, SP, Brasil, 1996. 